\title{
The Application of Formative Assessment in College English Teaching
}

\author{
Xue Liu \\ Beijing Institute of Graphic Communication \\ Beijing, 102600, China
}

\begin{abstract}
As the process of globalization is accelerating and the world today is becoming increasingly competitive, English learning meets the demand of self-development and social progress. Traditional Summative assessment cannot meet today's demand of English teaching. A more comprehensive way, Formative Assessment should be applied in Collage English Teaching process. In this work, Firstly the Problem of Collage English Teaching was analyzed; and then the definition of formative assessment and comparison of different kinds of assessment was given, finally, the application of Formative Assessment In Collage English Teaching was demonstrated.
\end{abstract}

Keywords-Formative Assessment; Collage English; Teaching Process; Summative Assessment

\section{INTRODUCTION}

As the process of globalization is accelerating and the world today is becoming increasingly competitive, English learning meets the demand of self-development and social progress. English is the most important international language and English language skills are also essential to students of the 21 st century. College English (herein after referred to as $\mathrm{CE}$ ) is a compulsory basic course for all nonEnglish-major students of Chinese colleges and universities throughout the stage of higher education.

Due to the large area and population in China, regional high school entrance examination and national college entrance examination are adopted in which it is impossible to conduct oral tests. Accordingly, English teachers in middle school stake every effort to improve students' examination grades instead of their comprehensive abilities, hence resulting in so-called "deaf English" and "dumb English". As for CET-4 and CET-6, they have really made great contribution to China's college English teaching by drawing the attention of education departments, college directors and the whole society to English, especially college English, laying down higher objectives for college English learning and helping teachers to make some positive adjustments in their teaching courses. As a result, many universities even bind students' performance in CET- 4 and CET- 6 to their job assignments after graduation. However, with some changes in our social demands, students' oral English is more important than before. In this case, CET-4 and CET-6, as

This work was sponsored by the key project. No. 23190112019 of Beijing Institute of Graphic Communication standardized tests, seem unsatisfying with their inability to test students' practical English competence, low passing rate caused by over difficult questions and therefore, a great waste of manpower and material resources. Therefore, it is quite necessary to reform College English Curriculum and the test system of CET-4 as well as CET-6. Actually, CET4and CET-6, designed by the Ministry of Education to examine the implementation of College English Curriculum at college, should not be connected with Students' graduation and jobs. Instead, students' practical abilities in English should be attached importance to.

Released in 2007 by the Ministry of Education of the People s Republic of China, College English Curriculum Requirements ${ }^{[1]}$ clearly defined that the goal of CE teaching is to develop the students' comprehensive English language ability, especially listening and speaking skills, so that students can use English effectively in future work and other social activities.

In the last twenty years, formative assessment practices in the classroom (i.e., self-assessment, peer assessment, feedback) have been considered an essential element to improving student learning. There is evidence that selfassessment improves learning and helps students become more responsible and more independent. In addition, research has shown that working with peers in the classroom is an important means of promoting learning. Feedback given as part of formative assessment helps learners become aware of any gaps that exist between their desired goal and their current knowledge, understanding or skill, and this guides them through the actions necessary to obtain their goal. Although these findings are encouraging, in the field of general education some teachers and tutors seem to be indifferent to students' failures; even worse, a number of them have never heard about formative assessment). Still, because there has been so much attention on formative assessment lately, most of teachers and tutors now have a rough idea of what it is. If they are asked to explain formative assessment they might answer that it involves testing students in the middle of an ongoing instructional sequence and then using the tests results to improve instruction. Nonetheless, this definition is quite superficial and does not express an understanding of the value of formative assessment in the teaching and learning process. 


\section{THEORY}

Assessment is the process of gathering data. More specifically, assessment is the ways instructors gather data about their teaching and their students' learning (Hanna \& Dettmer, 2004). The data provide a picture of a range of activities using different forms of assessment such as: pretests, observations, and examinations. Once these data are gathered, you can then evaluate the student's performance. Evaluation, therefore, draws on one's judgment to determine the overall value of an outcome based on the assessment data. It is in the decision-making process then, where we design ways to improve the recognized weaknesses, gaps, or deficiencies.

\section{A. Type of assessment}

There are three types of assessment: diagnostic, formative, and summative. Although are three are generally referred to simply as assessment, there are distinct differences between the three.

\section{1) Diagnostic Assessment}

Diagnostic assessment can help you identify your students' current knowledge of a subject, their skill sets and capabilities, and to clarify misconceptions before teaching takes place (Just Science Now! n.d.). Knowing students' strengths and weaknesses can help you better plan what to teach and how to teach it.

Types of Diagnostic Assessments:

a) Pre-tests (on content and abilities)

b) Self-assessments (identifying skills and competencies) prompts)

c) Discussion board responses (on content-specific

d) Interviews (brief, private, 10-minute interview of each student)

\section{2) Summative assessment}

Summative assessment takes place after the learning has been completed and provides information and feedback that sums up the teaching and learning process. Typically, no more formal learning is taking place at this stage, other than incidental learning which might take place through the completion of projects and assignments.

Rubrics, often developed around a set of standards or expectations, can be used for summative assessment. Rubrics can be given to students before they begin working on a particular project so they know what is expected of them (precisely what they have to do) for each of the criteria. Rubrics also can help you to be more objective when deriving a final, summative grade by following the same criteria students used to complete the project.

High-stakes summative assessments typically are given to students at the end of a set point during or at the end of the semester to assess what has been learned and how well it was learned. Grades are usually an outcome of summative assessment: they indicate whether the student has an acceptable level of knowledge-gain - is the student able to effectively progress to the next part of the class? To the next course in the curriculum? To the next level of academic standing? See the section "Grading" for further information on grading and its affect on student achievement.

Summative assessment is more product-oriented and assesses the final product, whereas formative assessment focuses on the process toward completing the product. Once the project is completed, no further revisions can be made. If, however, students are allowed to make revisions, the assessment becomes formative, where students can take advantage of the opportunity to improve.

Types of Summative Assessment:

a) Examinations (major, high-stakes exams)

b) Final examination (a truly summative assessment)

c) Term papers (drafts submitted throughout the semester would be a formative assessment)

d) Projects (project phases submitted at various completion points could be formatively assessed)

e) Portfolios (could also be assessed during it's development as a formative assessment)

\section{f) Performances}

g) Student evaluation of the course (teaching effectiveness)

\section{h) Instructor self-evaluation}

\section{3) Formative Assessment}

Formative assessment provides feedback and information during the instructional process, while learning is taking place, and while learning is occurring. Formative assessment measures student progress but it can also assess your own progress as an instructor. For example, when implementing a new activity in class, you can, through observation and/or surveying the students, determine whether or not the activity should be used again (or modified). A primary focus of formative assessment is to identify areas that may need improvement. These assessments typically are not graded and act as a gauge to students' learning progress and to determine teaching effectiveness (implementing appropriate methods and activities).

In another example, at the end of the third week of the semester, you can informally ask students questions which might be on a future exam to see if they truly understand the material. An exciting and efficient way to survey students' grasp of knowledge is through the use of clickers. Clickers are interactive devices which can be used to assess students' current knowledge on specific content. For example, after polling students you see that a large number of students did not correctly answer a question or seem confused about some particular content. At this point in the course you may need to go back and review that material or present it in such a way to make it more understandable to the students. 
This formative assessment has allowed you to "rethink" and then "re-deliver" that material to ensure students are on track. It is good practice to incorporate this type of assessment to "test" students' knowledge before expecting all of them to do well on an examination.

Types of Formative Assessment:

a) Observations during in-class activities; of students non-verbal feedback during lecture

b) Homework exercises as review for exams and class discussions)

c) Reflections journals that are reviewed periodically during the semester

d) Question and answer sessions, both formalplanned and informal-spontaneous

e) Conferences between the instructor and student at various points in the semester

f) In-class activities where students informally present their results

g) Student feedback collected by periodically answering specific question about the instruction and their self-evaluation of performance and progress

\section{B. Defination of formative assessment}

Michael Scriven coined the terms formative and summative evaluation in 1967, and emphasized their differences both in terms of the goals of the information they seek and how the information is used.[2] For Scriven, formative evaluation gathered information to assess the effectiveness of a curriculum and guide school system choices as to which curriculum to adopt and how to improve it.[3] Benjamin Bloom took up the term in 1968 in the book Learning for Mastery to consider formative assessment as a tool for improving the teaching-learning process for students.[4] His subsequent 1971 book Handbook of Formative and Summative Evaluation, written with Thomas Hasting and George Madaus, showed how formative assessments could be linked to instructional units in a variety of content areas.[5] It is this approach that reflects the generally accepted meaning of the term today.[6] For both Scriven and Bloom, an assessment, whatever its other uses, is only formative if it is used to alter subsequent educational decisions.[2] Subsequently, however, Black and Wiliam have suggested this definition is too restrictive, since formative assessments may be used to provide evidence that the intended course of action was indeed appropriate

\section{PRINCIPLES IN IMPLEMENTING FormATIVE ASSESSMENT G}

\section{A. Student-Centered Principle}

The object of College English is to develop students' ability to use English in a well-rounded way. Students are the object to be assessed. The purpose of the assessment is to improve the students' learning efficiency. Students are supposed to actively participate in the activity, i.e. student self-evaluation and peer assessment. This means that students are involved in deciding how to demonstrate their learning. Developing assessment that supports learning and motivation is essential to the success of studentcentered approaches.

\section{B. Combination of Qualitative Assessment and Quantitative Assessment}

Summative assessment focuses on the quantity and extent of students' knowledge, while a single test result, like a finalterm exam score is sometimes inadequate to accurately reflect the student 's situation in language learning. While in formative assessment, students' attitude, hard-working, learning strategy and progress are all taken into account, thus may provide a more comprehensive appraisal to students' performance. Due to the complexity of language ability assessment, the mixed use of qualitative assessment and quantitative assessment is particularly necessary in language teaching.

\section{Diverse In-Process Means of Assessment}

Diverse means of assessment include an oral test, written task, in-class performance, on-line self learning data, extracurricular activity, questionnaires, standard testing, team competitions and activity records. Formative assessment aims to make an appraisal both on students' achievement and progress in mastering basic knowledge and skills and their attitude towards learning activity. It also serves to provide feedback on the effectiveness of their learning strategies.

\section{Backwash Effects on Teaching}

The result of the formative assessment will produce beneficial backwash effect on language teaching. Teachers are supposed to make full use of the result of the formative assessment to reflect on their own teaching. They should always be alert of the effectiveness of their teaching method and adjust them to better meet the students' needs. Formative assessment allows teachers' teaching process to be subjected to observation, evaluation and self-supervision, thus contributing to the enhancement of their teaching effectiveness.

\section{APPlication OF Formative ASSESSMENT IN COLLEGE ENGLISH TEACHING}

\section{A. Self-Assessment}

Self-assessment means that college students have the ability to make evaluation on their own performance in the process of language learning. For example, they may ask questions like whether they are active in class in answering questions or getting involved in group discussion; how well they do in finishing their assignment; whether they pay enough attention to pronunciation and intonation; Are they fluent enough in reading texts? Are they familiar with the new words in the context? Are they better at guessing the meanings of new words through the context than before without looking up the dictionary every time? Are the methods used in language learning as efficient as expected? What progress have they made? Which learning strategies 
remain to be employed and which ones ought to be discarded? In making selfevaluation, they are expected to raise the awareness that they should be responsible for their learning, rather than the teacher.

\section{B. Peer Assessment}

Peer assessment is the evaluation made among learners themselves. Students are divided into several small groups. Each member of the group is responsible to score other partners according to certain evaluation criteria. For instance, each evaluator is asked to write comment on a certain student's learning behavior, pointing out his or her merits and meanwhile offers advice for improvement. And accordingly, the assessed student is supposed to reflect on peers' opinion and work out a plan of his own for improvement. In order to make the students get familiar with this evaluation approach, the teacher should work as a role model first. By experiencing this peer assessment, students get to fully understand the requirement of the teacher and the course, which will better guide their learning effort. The most valuable aspect of this process lies in the opportunity to learn from each other and trust and cooperate with partners. Fair, friendly discussions carried out among peers, can eliminate their worries and pressure in language learning and make them more selfconfident.

\section{Teacher Assessment}

Teacher assessment is the most important form of formative evaluation. A teacher can make judgment on a student's performance in various ways. The most frequently used is assignment, including written work, oral assignment, comprehensive reading assignment and presentation assignment 。 Both in-class tasks and outof-class assignment are to be counted. Besides, there are also short term work and long term project for the learners to accomplish. There is also the division of individual assignment and group work. Various forms of tests can be employed to inspect and supervise students' achievement. These tests and quizzes serve to diagnose and regulate students' learning strategies. Regular, flexible tests provide reliable evidence to examine the development of students' learning abilities. Learning attitude and in-class behavior are another aspect of formative assessment. In the completion of a learning task or series of tasks, students demonstrate different effort and enthusiasm towards learning activity which is to a great extent relevant to their learning achievement. This kind of evaluation requires that the teacher observes closely the students' state of mind, that is, whether they are willing to get involved, whether they are attentive in learning.

\section{Quantitative Evaluation}

For quantitative assessment of the learners, students need to actively participate in the learning activity. Questions are often designed for the students to answer to gather specific information rather than a general opinion about the course in this type of evaluation. The students can do this type of performance evaluation throughout the teaching semester or just at the end of the course.

\section{E. Qualitative Evaluation}

A qualitative evaluation is designed to assess the quality of the students' performance. This type of evaluation generally only works if the teacher is conducting the evaluation throughout the course work. Not only does the teacher want the students' opinion on how they feel about comprehending the coursework but he also wants to make assessment on the quality of work that is submitted. This type of student performance evaluation is more based on content and will be less affected by class size.

\section{F. In-Class Assessment}

Successful students are inevitably active learners in class. They show much willingness and interest even enthusiasm in the language learning process. And their active involvement in learning activities in class will in turn enhance their learning efficiency and improve their learning achievement. Teachers should always encourage students to take an active part in learning activity by commenting, scoring and keeping a record of students' classroom activity and study results or even by conducting interviews or hold meetings to discuss them in classroom performance. Oral English test, as a most typical subjective language test, is an effective and most often used means in checking students' language study in class.

\section{SUMMARY}

Formative assessment is more valuable in daily teaching to adapt to the needs of the students. In the process of formative assessment teachers can monitor students' progress, and modify the instruction accordingly. While the students, by getting feedback from their peers as well as the teacher, can monitor their own learning process. In language teaching and learning, formative assessment focuses on the process, which describes the ongoing situation of the students' language study. Students are provided with opportunities to get involved in modifying and planning the upcoming classes. In consequence, their autonomy in language learning is motivated and their awareness of using effective learning strategy is raised. Evaluation should also include that of the teachers, i.e., the assessment of their teaching processes and effects. In addition to teachers' attitudes, approaches, and methods, the content and organization of their curricula and the teaching effectiveness should also be considered.

\section{REFERENCES}

[1] Ministry of Education of the People's Republic of China. (July 2007). College English Curriculum Requirements. [Online]. p. 1. Available: http://www.moe.gov.cn/publicfiles/business/htmlfiles/moe/moe_1846 /201011/xxgk 110825.html

[2] Scriven, Michael (1967). "The methodology of evaluation". In Stake, R. E. Curriculum evaluation. Chicago: Rand McNally. American Educational Research Association (monograph series on evaluation, no. 1

[3] Wiliam, Dylan (2006). "Formative assessment: getting the focus right". Educational Assessment 11: 283-289. doi:10.1080/10627197.2006.9652993. 
[4] Bloom, Benjamin S. (1968). Learning for mastery. Los Angeles, USA: University of California press.

[5] Bloom,, Benjamin S.; Hasting, Thomas and Madaus, George (1971). Handbook of formative and summative evaluation of student learning. New York, USA: McGraw-Hill.

[6] Black, Paul; Wiliam, Dylan (1998). "Assessment and classroom learning". Assessment in Education: Principles, Policy \& Practice 5 (1). 